\title{
Government Subsidy and Crash Risk
}

\author{
Yuanzhi Chen, Chunqiang Wu \\ School of Business Administration, South China University of Technology, Guangzhou, China \\ Email: yzhchen@scut.edu.cn
}

How to cite this paper: Chen, Y. Z., \& Wu, C. Q. (2016). Government Subsidy and Crash Risk. Journal of Financial Risk Management, 5, 189-201.

http://dx.doi.org/10.4236/jfrm.2016.53019

Received: August 29, 2016

Accepted: September 27, 2016

Published: September 30, 2016

Copyright $\odot 2016$ by authors and Scientific Research Publishing Inc. This work is licensed under the Creative Commons Attribution International License (CC BY 4.0).

http://creativecommons.org/licenses/by/4.0/

\begin{abstract}
Using the sample of companies listed on Chinese GEM between 2009 and 2015, we examines the impact of government subsidy on companies' future stock price crash risk and explores how the earning information opacity moderates the relation between government subsidy and crash risk. We find that: 1) the government subsidies for the listed companies increase their crash risk; 2) the firms with higher information opacity are exposed to higher stock price crash risk; 3) considering the cross effect of opacity and government subsidy, the positive correlation between government subsidy and crash risk is weakened under the high information opacity environment. With further analysis, we find that that government subsidy dominates the earning management level of Jones model while measuring firm's information opacity. This paper not only enriches the study of external influencing factors of crash risk, but also broadens the study of government subsidy efficiency and provides a new decision basis for the investors to recognize the firms' earning information quality.
\end{abstract}

\section{Keywords}

Stock Price Crash Risk, Government Subsidy, Earning Information Opacity

\section{Introduction}

In recent years, stock markets are exposed to sharp fall frequently. Late in June 2015, thousands of shares in Chinese stock market fell by $10 \%$, the maximum allowed in one day, the SH index fell nearly 1000 points and GEM index shrank for more than $25 \%$. At the beginning of 2016, the Chinese stock market put on the "crash 3.0", with nearly 7 trillion market value evaporated. The phenomenon of collapse has brought great challenges to the financial market stability and the topic of crash risk has attracted a lot of market attention. In academic area, Jin \& Myers (2006) took the lead in clarifying the formation mechanism of crash risk from the perspective of information theory. The executives, for some motivation, would try to hide the bad news. Once accumulated to 
a certain threshold, the bad news would be released to the market, leading to the sharp fall of stock price. In this framework, the following documents may study the motivation of executives hoarding the bad news, such as the pursuit of equity incentive (Kim et al., 2011) and the excess compensation (Xu et al., 2014). Some also explore the impact factors on the stock price crash risk from the company's internal characteristics, such as the disclosure of internal control information (Ye Kangtao et al., 2015), the shareholding ratio of institutional investors (Cao Feng et al., 2015), the ownership of large shareholders (Wang Huacheng et al., 2015) and overinvestment (Jiang Xuanyu \& $\mathrm{Xu}$ Nianxing, 2015). Moreover, some investigate it from the external environment, such as political factors (Piotroski et al., 2015), analysts' optimistic bias (Xu Nianxing, Jiang Xuanyu et al., 2012), religion (Callen \& Fang, 2012) and other aspects.

On the other hand, the government subsidy is a way for government to allocate resources. Characteristics of high-tech content and emerging industry clustering make all GEM listed companies highly favored by government. As of December 31, 2014, a total of 419 companies have gained government subsidies, with the cumulative amount reached more than 34 billion yuan. Such huge amount of government subsidies, with methods of financial return, tax incentives, special subsidy and innovation award etc., have become a major source of corporate profits, providing convenience for enterprises' earnings management behavior. That is why the government subsidy is criticized repeatedly as "GEM's last straw". However, as for the problem of efficiency of government subsidy, there is no consistent conclusion. Most scholars believe that government subsidies bring free cash flow for enterprises so that it improves the short-term solvency of enterprises (Tzelepis \& Skuras, 2004; Zou et al., 2006). It is conducive to improve the short-term performance of enterprises (Chen Xiaohe \& Lee Jing, 2001). But in the long term, it doesn't promote the profitability of enterprises (Tzelepis \& Skuras, 2004) and may even have adverse effects (Leng Jianfei, Wang Kai, 2007). Tang \& Luo (2007) investigate the function of government subsidy on the listed companies from aspects of social and economic benefits and they find that it does not have a significant impact on economic benefits. Yu Minggui and his colleagues (2012) suggest that the consequence of government subsidy depends on the degree of political connection.

Taken altogether, we have not yet found any relevant literatures that discuss about the relationship between companies' stock price crash risk and government subsidy so far. Therefore, this paper approaches the efficiency of government subsidy in the perspective of crash risk and then discusses its function mechanism.

Using the sample of the GEM listed companies which received government grants between 2009 and 2014, we discuss the effects of government subsidy on the GEM stock price crash risk. We find that: 1) the government subsidy for the listed companies significantly improves their crash risk; 2) the higher the information opacity, the higher the GEM stock price crash risk ; 3) considering the cross effect of information opacity and government subsidy, the positive correlation between government subsidy and crash risk is weakened while the opacity is high. Further analysis shows that on the 
proxy variable for the opacity of information, government subsidy should be better than the earning management level measured by Jones model.

The contribution of this paper may be reflected in the following aspects. First, this paper studies the impact of government subsidy on the company's stock price crash risk. It not only enriches the emerging study of crash risk, but also provides a new research path for the efficiency of government subsidy. Second, information opacity is an important factor of the crash risk, and earning management level using the Jones model is often taken as its proxy value. But this study shows that government subsidy dominates this common proxy, which provides a new way to measure the opacity of information.

The paper proceeds as follows. Section 2 reviews prior literature and develops our hypotheses. Section 3 describes the sample, variables measurement and research design. Section 4 presents the empirical results. Section 5 shows the further analysis and section 6 shows robustness test. Section 7 concludes.

\section{Theoretical Analysis and Research Assumptions}

The stock price crash risk refers to the phenomena that company's share price fall sharply. Romer (1992) is the first to reveal the cause of this phenomenon from the perspective of information disclosure. Jin \& Myers (2006) confirmed this formation mechanism with the cross-border data and found that under the motivation of salary contract, occupation career and empire building, executives chose to hide the negative news. When negative news accumulated to a certain threshold, they would be poured into the market as a whole, resulting in the crash of company stock price. Hutton et al (2009) took the level of earnings management as a proxy for corporate information opacity and found the more opaque the company information was, the more the share price tended to crash. Francis et al. (2012) discussed from the perspective of the reliability of financial information analysis and concluded that real earning management behavior would push up the stock price crash risk in the future. Therefore, the root of stock price crash was asymmetry of information. As executives hold more information, they would tend to adopt the opportunism behavior and adversely affected the company's share price performance. Under the imperfect system in our country, when the company specific information content is lower, the risk of a crash shows higher (Jin \& Myers, 2006; Piotroski \& Wong, 2010). Based on this, hypothesis 1 is proposed below:

$\mathrm{H} 1$ : in the case of other conditions unchanged, the higher the company's information opacity, the higher the crash risk of the company's share price.

Government subsidy is an important way for government to intervene in the economy. The research on the efficiency of government subsidy first focused on the employment rate, and then extended to the enterprise performance. Chen \& Li (2001) found that the local government conducted earning management for the local listed companies through government subsidy for the sake of winning over local resources, but this behavior would bring about a serious distortion of the accounting information. Although government subsidy can improve corporate performance in the short term (Zou 
et al., 2006), it concealed the firm's operation problems. Companies that obtain government grants may show lower specific information content and would be exposed to higher crash risk. Shi et al. (2014) found that in places with high degree of marketization, government undertook fewer interventions in business and earning management was kept in a low level so that the stock price crash risk was also relatively low. Based on this, we put forward hypothesis 2 :

$\mathrm{H} 2$ : in the case of other conditions unchanged, the higher the level of government subsidy to the company is, the higher crash risk of the company's stock price is.

Opacity of information is the enterprise's own characteristics. Government subsidy, a way of earning management for listed companies, in a certain extent reduces the firm specific information content, so the company's share price crash is more likely to occur. Kim \& Zhang (2012) found that the negative correlation between accounting conservatism and crash risk is more prominent in companies with higher information opacity. Based on this, we proposed hypothesis 3:

H3: in the case of other conditions unchanged, high information opacity will enhance the positive correlation between government subsidy and the crash risk.

\section{Research Design}

\subsection{Sample Selection and Data Sources}

The initial sample comprises firm-year observations for which government subsidy information is available on CSMAR. In addition, we collect: 1) CSMAR daily stock files to estimate our measures of firm-specific crash risk; 2) firm-level accounting data from Gildata annual files. We restrict our CSMAR sample to common industries, exclusive of finance and insurance industry. We also exclude the stocks with weekly return data per year less than 26. Our final sample consists of 1350 firm-year observations for the years 2009-2015. In addition, we winsorize continuous variables except for proxy variables of crash risk in 1\% and 99\%, and conduct cluster adjustment in the industry level.

\subsection{Variables Definition}

\subsubsection{Crash Risk}

Following prior literature (Chen et al, 2001; Kim, 2011a, 2011b; Xu Nianhang, 2012), we employ two firm-specific measures of stock price crash risk: NCSKEW and DUVOL. First, we first estimate firm-specific weekly returns from the following expanded market and industry index model regression for each firm and year:

$$
r_{i, t}=\beta_{i, 0}+\beta_{i, 1} r_{m, t-2}+\beta_{i, 2} r_{m, t-1}+\beta_{i, 3} r_{m, t}+\beta_{i, 4} r_{m, t+1}+\beta_{i, 4} r_{m, t+2}+\varepsilon_{i, t}
$$

where $r_{i, t}$ is weekly return considering cash dividend reinvestment on stock $i$ in week $t, r_{m, t}$ is the return on the GEM value-weighted market index considering the cash dividend reinvestment in week $t . \varepsilon_{i, t}$ is the residual of the regression. We then define the firm-specific weekly return $W_{i, t}$ as below:

$$
W_{i, t}=\ln \left(1+\varepsilon_{i, t}\right) \text {. }
$$

Thus, we construct the following two indicators: 
1) the negative coefficient of skewness of firm-specific daily returns (NCSKEW)

$$
\operatorname{NCSKEW}_{i, t}=-\frac{n(n-1)^{3 / 2} \sum W_{i, t}^{3}}{(n-1)(n-2)\left(\sum W_{i, t}^{2}\right)^{3 / 2}}
$$

where $n$ is the number of observations of firm-specific weekly returns during the fiscal year $t$. A high value of NCSKEW indicates a serious negative skewness, thus a high level of crash risk of stock price.

2) the down-to-up volatility of firm-specific daily returns (DUVOL)

$$
\text { DUVOL }_{i, t}=\log \left[\frac{\left(n_{u}-1\right) \sum_{\text {DOWN }} W_{i, t}^{2}}{\left(n_{d}-1\right) \sum_{\mathrm{UP}} W_{i, t}^{2}}\right]
$$

where $n_{u}$ and $n_{d}$ are the number of up and down weeks over the fiscal year $t$, respectively. For any stock $i$ over a one-year period, we separate all the weeks with firm-specific weekly returns above (below) the mean of the period and call this the "up" ("down") sample. We than calculate the sum of the square of $W_{i, t}$ for the "up" and "down" samples separately. Similar to NCSKEW, a large value of DUVOL indicates a high level of stock price crash risk.

\subsubsection{Earning Information Opacity}

We use the company's earning management level as a proxy variable of corporate information opacity. The company's operating earnings management level is obtained through the Jones model:

$$
\frac{\text { Accruals }_{t}}{A_{t-1}}=\alpha_{0}+\beta_{1} \frac{1}{A_{t-1}}+\beta_{2} \frac{S_{t}-S_{t-1}}{A_{t-1}}+\beta_{3} \frac{P^{P P E}}{A_{t-1}}+\varepsilon_{t} .
$$

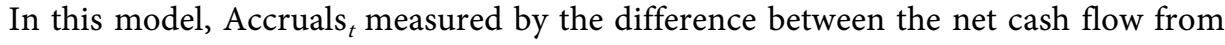
operating activities and the operating profit, indicates the operating earning management level. $A_{t-1}$ refers to total assets at the beginning of the year, $S_{t}$ is the primary business income and $\mathrm{PPE}_{t}$ is the net worth of fixed asset.

We take the absolute value of $\varepsilon_{i, t}$ as the company's earnings management level in year $t$, and referring to the model used by Hutton et al. (2009), we measure firm is information opacity in year $t$ with moving average of its three phase lag, that is:

$$
\operatorname{Acc}_{i, t}=\frac{\left|\varepsilon_{i, t-2}\right|+\left|\varepsilon_{i, t-1}\right|+\left|\varepsilon_{i, t}\right|}{3} .
$$

\subsubsection{Control Variables}

Following prior literature (Hong, 2001; Xu Nianhan, 2012), we employ the following control variables: company size $\left(\operatorname{Size}_{i, t}\right)$, company's market to book rate $\left(\mathrm{Pb}_{i, t}\right)$, return on total assets $\left(\mathrm{Roa}_{i, t}\right)$, asset-liability ratio $\left(\mathrm{Da}_{i, t}\right)$, the average of company's specific weekly return rate $\left(\operatorname{Ret}_{i, t}\right)$, the standard deviation $\left(\operatorname{Sigma}_{i, t}\right)$, abnormal turnover rate $\left(\operatorname{Yturn}_{i, t}\right)$, fund shareholding ratio $\left(\right.$ Fund $\left._{i, t}\right)$. We also introduce the dummy variable of industry and year in all regressions to control the year and industry's impact. The definition of each variable is shown in Table 1. 
Table 1. Definition of variables.

\begin{tabular}{|c|c|c|}
\hline Variables & Symbols & Variable Definition \\
\hline \multirow{2}{*}{$\begin{array}{l}\text { Dependent } \\
\text { Variable }\end{array}$} & NCSKEW $_{i, t+1}$ & $\begin{array}{l}\text { Indicator of the company's stock price crash risk, } \\
\text { calculated by the formula ( } 3 \text { ) }\end{array}$ \\
\hline & DUVOL $_{i, t+1}$ & $\begin{array}{l}\text { Indicator of the company's stock price crash risk, } \\
\text { calculated by the formula ( } 4)\end{array}$ \\
\hline \multirow{2}{*}{$\begin{array}{l}\text { Independent } \\
\text { Variable }\end{array}$} & $\operatorname{Lngg}_{i, t}$ & $\begin{array}{l}\text { Government subsidy, calculated by the natural logarithm of } \\
\text { the amount of government subsidy for company } i \text { in year } t\end{array}$ \\
\hline & $\operatorname{Acc}_{i, t}$ & Information opacity, calculated by the formula (5) (6) \\
\hline \multirow{8}{*}{$\begin{array}{l}\text { Control } \\
\text { Variables }\end{array}$} & $\mathrm{Pb}_{i, t}$ & Firm $i$ s market to book rate in year $t$ \\
\hline & $\mathrm{Da}_{i, t}$ & Asset-liability ratio of firm $i$ in year $t$ \\
\hline & $\operatorname{Size}_{i, t}$ & $\begin{array}{c}\text { Firm size, calculated by the natural logarithm of the } \\
\text { amount of total assets of firm } i \text { in year } t\end{array}$ \\
\hline & $\operatorname{Roa}_{i, t}$ & Firm $i$ s operating profit divided by total assets in year $t$ \\
\hline & $\operatorname{Ret}_{i, t}$ & The average of firm is specific weekly return rate \\
\hline & $\operatorname{Sigma}_{i, t}$ & The standard deviation of firm $i$ s specific weekly return rate in year $t$ \\
\hline & Fund $_{i, t}$ & Firm $i$ s fund shareholding ratio in year $t$ \\
\hline & Yturn $_{i, t}$ & $\begin{array}{l}\text { Abnormal turnover rate, calculated by the difference between annual } \\
\text { turnover rate in year } \mathrm{t} \text { and annual turnover rate in year } t-1\end{array}$ \\
\hline
\end{tabular}

\subsubsection{Model Designation}

To test hypotheses 1 and 2, this paper builds the following models:

$$
\begin{aligned}
& \operatorname{NCSKEW}_{i, t+1}=\beta_{0}+\beta_{1} \mathrm{Acc}_{i, t}+\sum_{k} \beta_{k} \mathrm{CONTROL}_{t}^{(k)}+\sum \text { Industry }+\sum \text { Year }+\varepsilon_{i, t} \\
& \operatorname{DUVOL}_{i, t+1}=\beta_{0}+\beta_{1} \mathrm{Acc}_{i, t}+\sum_{k} \beta_{k} \mathrm{CONTROL}_{t}^{(k)}+\sum \text { Industry }+\sum \text { Year }+\varepsilon_{i, t} \\
& \operatorname{NCSKEW}_{i, t+1}=\beta_{0}+\beta_{1} \operatorname{Lngg}_{i, t}+\sum_{k} \beta_{k} \mathrm{CONTROL}_{t}^{(k)}+\sum \text { Industry }+\sum \text { Year }+\varepsilon_{i, t} \\
& \text { DUVOL }_{i, t+1}=\beta_{0}+\beta_{1} \operatorname{Lngg}_{i, t}+\sum_{k} \beta_{k} \operatorname{CONTROL}_{t}^{(k)}+\sum \text { Industry }+\sum \text { Year }+\varepsilon_{i, t} .
\end{aligned}
$$

We expect that among these models the coefficient of information opacity $\operatorname{Acc}_{i, p}$ is positive, so it is with the coefficient of government subsidy $\operatorname{Lngg}_{i, t}$. To dig out how the information opacity functions the correlation between the government subsidy and stock price crash risk, this paper introduces the cross term of information opacity and government subsidy. The following model is obtained:

$$
\begin{aligned}
\operatorname{NCSKEW~}_{i, t+1}= & \beta_{0}+\beta_{1} \operatorname{Lngg}_{i, t}+\beta_{2} \operatorname{Acc}_{i, t}+\sum_{k} \beta_{k} \text { CONTROL }_{t}^{(k)}+\sum \text { Industry } \\
& +\sum \text { Year }+\varepsilon_{i, t} \\
\text { DUVOL }_{i, t+1}= & \beta_{0}+\beta_{1} \operatorname{Lngg}_{i, t}+\beta_{2} \text { Acc }_{i, t}+\sum_{k} \beta_{k} \operatorname{CONTROL}_{t}^{(k)}+\sum \text { Industry } \\
& +\sum \text { Year }+\varepsilon_{i, t}
\end{aligned}
$$




$$
\begin{aligned}
\operatorname{NCSKEW~}_{i, t+1}= & \beta_{0}+\beta_{1} \operatorname{Lngg}_{i, t}+\beta_{2} \operatorname{Acc}_{i, t}+\beta_{3} \operatorname{Lngg}_{i, t} * \operatorname{Acc}_{i, t}+\sum_{k} \beta_{k} \operatorname{CONTROL}_{t}^{(k)} \\
& +\sum \text { Industry }+\sum \text { Year }+\varepsilon_{i, t} \\
\text { DUVOL }_{i, t+1}= & \beta_{0}+\beta_{1} \operatorname{Lngg}_{i, t}+\beta_{2} \operatorname{Acc}_{i, t}+\beta_{3} \operatorname{Lngg}_{i, t} * \operatorname{Acc}_{i, t}+\sum_{k} \beta_{k} \operatorname{CONTROL}_{t}^{(k)} \\
& +\sum \text { Industry }+\sum \text { Year }+\varepsilon_{i, t} .
\end{aligned}
$$

If the result is consistent with our assumptions, the coefficient of cross term $\operatorname{Acc}_{i, t}{ }^{*}$ Lngg $_{i, t}$ should be positive.

\section{Empirical Result Analysis}

\subsection{Descriptive Statistics}

As Table 2 stated, 1) the average values of NCSKEW and DUVOL are -0.440 and -0.150 , respectively, while the standard deviations are 0.950 and 0.330 . This indicates that the difference of NCSKEW among sample firms is relatively large, but DUVOL is relatively stable. 2) The average value of Lngg is 15.590 , is slightly lower than its mean value of 15.640. Among the GEM sample firms, firms with high government subsidy hold a high proportion than that with low government subsidy. 3) The average value of Acc is 0.080 , indicates that GEM listed companies generally conduct earning management.

\subsection{Correlation Analysis}

As Table 3 shows, the correlation coefficient between NCSKEW N $_{t+1}$ and DUVOL D $_{t+1}$ is 0.9141 , significant at the $1 \%$ level, suggesting that these two indicators are consistent in terms of stock price crash risk. And the correlation coefficients between government subsidy and these two indicators are 0.0871 and 0.0861 , statistically significant at the

Table 2. Variable description.

\begin{tabular}{ccccc}
\hline Variable & Mean & Sd & Min & Median \\
\hline NCSKEW & -0.440 & 0.950 & -4.080 & -0.400 \\
DUVOL & -0.150 & 0.330 & -1.280 & -0.140 \\
Acc & 0.080 & 0.050 & 0.010 & 0.070 \\
Lngg & 15.590 & 1.130 & 12.070 & 15.640 \\
Yturn & 0.070 & 0.150 & -0.070 & 0.000 \\
Fund & 0.050 & 0.070 & 0.000 & 0.030 \\
Ret & 0.000 & 0.010 & -0.020 & 0.000 \\
Sigma & 0.060 & 0.030 & 0.020 & 0.050 \\
Pb & 10.880 & 8.160 & 2.080 & 8.390 \\
Da & 0.230 & 0.150 & 0.020 & 0.190 \\
Size & 20.900 & 0.580 & 19.710 & 20.830 \\
\hline
\end{tabular}


Table 3. Pearson correlation coefficient of main variables.

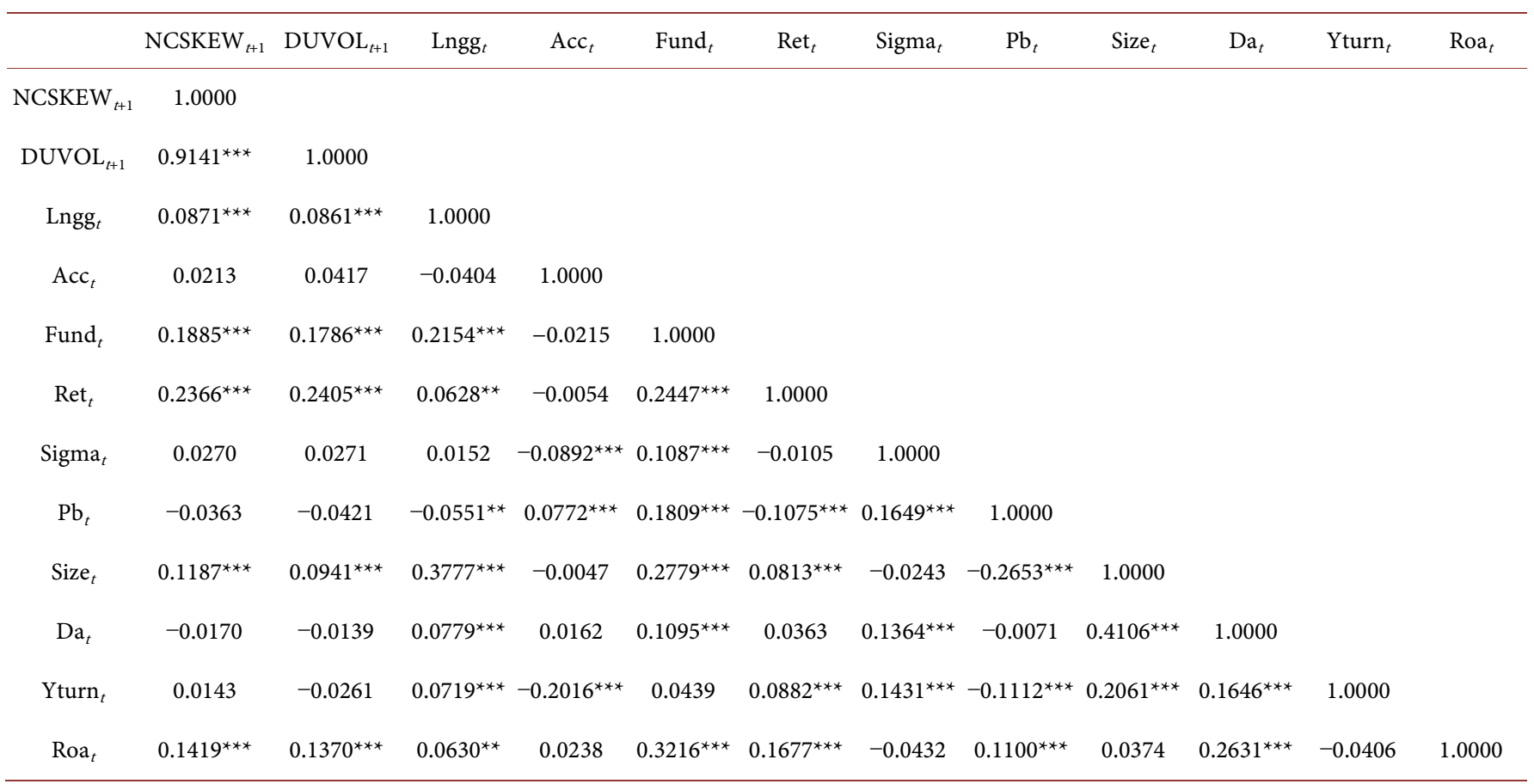

$1 \%$ level. The positive relationship shows that without considering other factors, the higher the government subsidy, the higher one-year forward crash risk, consistent with the hypothesis of H2. However, information opacity doesn't share a significant relationship with future crash risk. In addition, the relationship between government subsidy Lngg $_{t}$ and firm's asset profit margin in the same period Roa $_{t}$ is positive, proves that the government subsidy can help improve the firm's short-term operation.

\subsection{Regression Analysis}

Table 4 shows the regression results of model (5) (6) (7) (8). In the regression equation (a) (b), the coefficients of information opacity (Acc) were 0.391 and 0.134 , significant in the $5 \%$ level, consistent with hypothesis 1 . In the equation (a) and (b), the coefficients of government subsidy Lngg were 0.0150 and 0.009 , respectively. With the latter significant in the $1 \%$ level, we deduce that the higher level of government subsidy, the higher one-year ahead crash risk of the company's share price, therefore the hypothesis 2 is validated. With regards the control variables, Fund, Ret, Size, Roa were all positive significantly at the $1 \%$ level, suggesting that with other conditions unchanged, companies with higher proportion of fund shareholdings, higher specific return rate, bigger firm size as well as greater return on total assets, are more inclined to suffer stock price crash in the capital market, consistent with previous studies on the whole.

In the model equation (e) and (f), the relationship between government subsidy (Lngg) and company information opacity (ACC) were both significantly positive, verifying hypothesis 1 and hypothesis 2 again. Adding the cross term of government subsidy (Lngg) and company information opacity, the coefficient of government subsidy 
Table 4. Basic regression results.

\begin{tabular}{|c|c|c|c|c|}
\hline \multirow{3}{*}{ Variables } & \multicolumn{4}{|c|}{ Coefficients and t-value } \\
\hline & (a) & (b) & (c) & (d) \\
\hline & NCSKEW $_{i, t+1}$ & $\operatorname{DUVOL}_{i, t+1}$ & NCSKEW $_{i, t+1}$ & DUVOL $_{i, t+1}$ \\
\hline \multirow{2}{*}{$\operatorname{Acc}_{i, t}$} & $0.391^{\star *}$ & $0.134^{* *}$ & & \\
\hline & $(0.17)$ & $(0.06)$ & & \\
\hline \multirow{2}{*}{$\operatorname{Lngg}_{i, t}$} & & & 0.0150 & $0.009^{* * *}$ \\
\hline & & & $(0.01)$ & $(0.00)$ \\
\hline \multirow{2}{*}{ Fund $_{i, t}$} & $1.608^{* * *}$ & $0.576^{* * *}$ & $1.567^{\star \star *}$ & $0.555^{\star * *}$ \\
\hline & $(0.22)$ & $(0.07)$ & $(0.21)$ & $(0.07)$ \\
\hline \multirow{2}{*}{$\operatorname{Ret}_{i, t}$} & $26.678^{* * *}$ & $9.076^{* * *}$ & $26.836^{* * *}$ & $9.058^{* * *}$ \\
\hline & $(2.12)$ & $(0.90)$ & $(2.03)$ & $(0.88)$ \\
\hline \multirow{2}{*}{ Sigma $_{i, t}$} & 0.0370 & 0.732 & -0.00200 & 0.728 \\
\hline & $(1.60)$ & $(0.71)$ & $(1.54)$ & $(0.70)$ \\
\hline \multirow{2}{*}{$\mathrm{Pb}_{i, t}$} & $-0.002^{*}$ & -0.00200 & -0.00200 & -0.00200 \\
\hline & $(0.00)$ & $(0.00)$ & $(0.00)$ & $(0.00)$ \\
\hline \multirow{2}{*}{$\operatorname{Size}_{i, t}$} & $0.156^{* * *}$ & $0.036^{* * *}$ & $0.145^{\star * *}$ & $0.029^{* * *}$ \\
\hline & $(0.03)$ & $(0.00)$ & $(0.04)$ & $(0.00)$ \\
\hline \multirow{2}{*}{$\mathrm{Da}_{i, t}$} & -0.245 & -0.00700 & -0.226 & 0.000 \\
\hline & $(0.28)$ & $(0.07)$ & $(0.28)$ & $(0.07)$ \\
\hline \multirow{2}{*}{ Yturn $_{i, t}$} & -0.0900 & 0.0150 & -0.127 & 0.00200 \\
\hline & $(0.43)$ & $(0.16)$ & $(0.41)$ & $(0.15)$ \\
\hline \multirow{2}{*}{$\operatorname{Roa}_{i, t}$} & $1.326^{* * *}$ & $0.426^{* * *}$ & $1.376^{* * *}$ & $0.442^{* * *}$ \\
\hline & $(0.43)$ & $(0.12)$ & $(0.44)$ & $(0.13)$ \\
\hline \multirow{2}{*}{ Cons } & $-3.612^{* * *}$ & $-0.907^{\star * *}$ & $-3.560^{* * *}$ & $-0.889^{\star * *}$ \\
\hline & $(0.71)$ & $(0.11)$ & $(0.73)$ & $(0.11)$ \\
\hline Industry & fixed & fixed & fixed & fixed \\
\hline \multicolumn{5}{|l|}{ Year } \\
\hline $\mathrm{N}$ & 1355 & 1372 & 1350 & 1367 \\
\hline $\mathrm{R} 2$ & 0.102 & 0.106 & 0.104 & 0.107 \\
\hline Adj-R2 & 0.0850 & 0.0900 & 0.0860 & 0.0890 \\
\hline
\end{tabular}

(Lngg) kept positive, moreover, were both significant in the level of $10 \%$. In the regression equation (g), the coefficient of the cross term was -0.648 , significant in the level of $5 \%$. However, this result is incompatible with our assumption. It suggests that in the companies whose information opacity is low, the positive relationship between government subsidy and future crash risk is not suppressed, instead, would have a callback. As for other variables, the results are basically the same with that in Table 5. 
Table 5. Regression results with cross term.

\begin{tabular}{|c|c|c|c|c|}
\hline \multirow{3}{*}{ Variables } & \multicolumn{4}{|c|}{ Coefficients and t-value } \\
\hline & (e) & (f) & (g) & (h) \\
\hline & NCSKEW $_{i, t+1}$ & DUVOL $_{i, t+1}$ & NCSKEW $_{i, t+1}$ & $\operatorname{DUVOL}_{i, t+1}$ \\
\hline \multirow{2}{*}{$\operatorname{Acc}_{i, t}$} & $0.399^{* *}$ & $0.143^{\star *}$ & $10.518^{\star *}$ & 1.304 \\
\hline & $(0.17)$ & $(0.06)$ & $(3.62)$ & $(0.98)$ \\
\hline \multirow{2}{*}{$\operatorname{Lngg}_{i, t}$} & $0.017^{\star}$ & $0.010^{* * *}$ & $0.073^{* *}$ & $0.016^{* *}$ \\
\hline & $(0.01)$ & $(0.00)$ & $(0.02)$ & $(0.01)$ \\
\hline \multirow{2}{*}{$\operatorname{Acc}_{i, t}{ }^{*} \operatorname{Lngg}_{i, t}$} & & & $-0.648^{\star *}$ & -0.0740 \\
\hline & & & $(0.23)$ & $(0.06)$ \\
\hline \multirow{2}{*}{ Fund $_{i, t}$} & $1.572^{\star * *}$ & $0.554^{\star * *}$ & $1.491^{\star * *}$ & $0.545^{\star * *}$ \\
\hline & $(0.22)$ & $(0.07)$ & $(0.19)$ & $(0.07)$ \\
\hline \multirow{2}{*}{$\operatorname{Ret}_{i, t}$} & $26.577^{\star * \star}$ & $9.017^{\star * *}$ & $26.920^{\star * *}$ & $9.058^{* * *}$ \\
\hline & $(2.06)$ & $(0.88)$ & $(2.14)$ & $(0.90)$ \\
\hline \multirow{2}{*}{ Sigma $_{i, t}$} & 0.0650 & 0.752 & 0.127 & 0.761 \\
\hline & $(1.59)$ & $(0.71)$ & $(1.63)$ & $(0.71)$ \\
\hline \multirow{2}{*}{$\mathrm{Pb}_{i, t}$} & -0.00200 & -0.00200 & -0.00200 & -0.00200 \\
\hline & $(0.00)$ & $(0.00)$ & $(0.00)$ & $(0.00)$ \\
\hline \multirow{2}{*}{ Size $_{\mathrm{i}, \mathrm{t}}$} & $0.145^{\star * *}$ & $0.029^{* * *}$ & $0.142^{* * *}$ & $0.029^{\star * \star}$ \\
\hline & $(0.04)$ & $(0.00)$ & $(0.04)$ & $(0.00)$ \\
\hline \multirow{2}{*}{$\mathrm{Da}_{i, t}$} & -0.240 & -0.00500 & -0.235 & -0.00500 \\
\hline & $(0.27)$ & $(0.07)$ & $(0.27)$ & $(0.07)$ \\
\hline \multirow{2}{*}{ Yturn $_{i, t}$} & -0.120 & 0.00200 & -0.129 & 0 \\
\hline & $(0.41)$ & $(0.15)$ & $(0.41)$ & $(0.15)$ \\
\hline \multirow{2}{*}{$\mathrm{Roa}_{i, t}$} & $1.348^{* * *}$ & $0.437^{\star * *}$ & $1.343^{* * *}$ & $0.437^{\star * *}$ \\
\hline & $(0.44)$ & $(0.13)$ & $(0.44)$ & $(0.13)$ \\
\hline \multirow{2}{*}{ Cons } & $-3.628^{* * *}$ & $-0.915^{\star * *}$ & $-4.433^{\star * *}$ & $-1.007^{* * *}$ \\
\hline & $(0.71)$ & $(0.11)$ & $(0.50)$ & $(0.09)$ \\
\hline Industry & Fixed & Fixed & Fixed & fixed \\
\hline \multicolumn{5}{|l|}{ Year } \\
\hline $\mathrm{N}$ & 1350 & 1367 & 1350 & 1367 \\
\hline $\mathrm{R} 2$ & 0.103 & 0.107 & 0.104 & 0.107 \\
\hline Adj-R2 & 0.0850 & 0.0900 & 0.0860 & 0.0890 \\
\hline
\end{tabular}

\section{Further Analysis}

Previous empirical results show that government subsidy would increase the future crash risk of the company's stock price, which illustrates to a certain degree that management tend to cover company negative information through the government subsidy. 
As we assumed, this method should have been adopted more generally under high opaque information environment. Nevertheless, our regression results in Table 6 show that the positive relationship between government subsidy and crash risk has not been inhibited in the companies with low information opacity. Does this mean that in the measure of information opacity government subsidy is better than the quantitative indicator of Jones model? In order to verify this, we first take government subsidy as the dependent variable and company information opacity as independent variable in the regression model as follows:

$$
\operatorname{Lngg}_{i, t+1}=\beta_{0}+\beta_{1} \mathrm{Acc}_{i, t}+\sum \text { Industry }+\sum \text { Year }+\varepsilon_{i, t} .
$$

With the residual obtained (here we defined it as Res), we replace the government subsidy in the model (5) and (6) with Res. The models are as follows:

$$
\begin{aligned}
\operatorname{NCSKEW~}_{i, t+1}= & \beta_{0}+\beta_{1} \operatorname{Res}_{i, t}+\beta_{2} \operatorname{Acc}_{i, t}+\sum_{k} \beta_{k} \text { CONTROL }_{t}^{(k)} \\
& +\sum \text { Industry }+\sum \text { Year }+\varepsilon_{i, t} \\
\operatorname{DUVOL}_{i, t+1}= & \beta_{0}+\beta_{1} \operatorname{Res}_{i, t}+\beta_{2} \text { Acc }_{i, t}+\sum_{k} \beta_{k} \text { CONTROL }_{t}^{(k)} \\
+ & +\sum \text { Industry }+\sum \text { Year }+\varepsilon_{i, t} .
\end{aligned}
$$

As stated in Table 6, in all regression equations, residual term Res shows positive effect on both two indicators of stock price crash risk, respectfully significant in $10 \%$ and $1 \%$ level. This proves our conjecture that government subsidy is a better measure of information opacity.

\begin{tabular}{|c|c|c|c|c|}
\hline \multirow[b]{2}{*}{ Variables } & \multicolumn{4}{|c|}{ Coefficients and t-value } \\
\hline & $\begin{array}{c}\text { (i) } \\
\text { NCSKEW }_{i, t+1}\end{array}$ & $\begin{array}{c}(\mathrm{j}) \\
\text { DUVOL }_{i, t+1}\end{array}$ & $\begin{array}{c}(\mathrm{k}) \\
\text { NCSKEW }_{i, t+1}\end{array}$ & $\begin{array}{c}\text { (l) } \\
\text { DUVOL }_{i, t+1}\end{array}$ \\
\hline $\operatorname{Acc}_{i, t}$ & & & $\begin{array}{c}0.383^{* *} \\
(0.17)\end{array}$ & $\begin{array}{c}0.133^{* *} \\
(0.06)\end{array}$ \\
\hline $\operatorname{Res}_{i, t}$ & $\begin{array}{l}0.017^{\star} \\
(0.01)\end{array}$ & $\begin{array}{c}0.010^{* * *} \\
(0.00)\end{array}$ & $\begin{array}{l}0.017^{\star} \\
(0.01)\end{array}$ & $\begin{array}{c}0.010^{* * *} \\
(0.00)\end{array}$ \\
\hline Control variables & Controlled & Controlled & Controlled & Controlled \\
\hline Industry & fixed & fixed & fixed & fixed \\
\hline Year & fixed & fixed & fixed & fixed \\
\hline $\mathrm{N}$ & 1350 & 1367 & 1350 & 1367 \\
\hline $\mathrm{R} 2$ & 0.102 & 0.107 & 0.103 & 0.107 \\
\hline Ad-R2 & 0.0850 & 0.0900 & 0.0850 & 0.0900 \\
\hline
\end{tabular}

\section{Robustness Test}

- As for the proxy variable of information opacity, we directly use the company's accruals earning management level measured by the Jones model (model 5), without

Table 6. Basic regression results. 
moving average, and the results come to be similar with above. In addition, we also use the modified Jones model to measure accrual earnings management level. It turns out that regardless of whether smoothing or not, the regression results are basically the same.

- In the screening of samples, we relaxed the requirement for the data volume of stocks weekly return rate, excluding the sample with less than 13 weekly return rate data per year, instead of 26 that we adopted initially. The result showed little difference with our initial results.

\section{Conclusions}

We investigate whether government subsidy is associated with future stock price crash risk. Using a large sample of companies listed on Chinese GEM from the years 2009 to 2015 , we find robust evidences that the government subsidy is positively related to oneyear ahead stock price crash risk. These findings enhance our understanding of government subsidy in predicting future stock price crash risk and corroborate our explanation of the role of government subsidy in hoarding bad news by managers.

Our empirical results also show that the earning information opacity would significantly increase its share price crash risk. However, the positive relation between government subsidy and future crash risk is more salient for firms with low information opacity, which is inconsistent with prior literature. Further analysis suggests that government subsidy is a better proxy variable for the opacity of information than earning management level measured by the Jones model. This provides a new way for studying the opacity information.

These findings also suggest that companies with higher proportion of fund shareholdings, higher specific return rate, bigger firm size as well as greater return on total assets, are more inclined to suffer stock price crash in the capital market. Hence, our study may provide investors with an effective strategy to help predict and eschew future stock price crash risk in their portfolio investment decisions.

Collectively, this study demonstrates how government subsidy is related to higher moments of the stock return distribution. However, government subsidizes companies through a variety of ways, including funding, tax return, fiscal interest discounts, tax return, etc. This study doesn't explore the association between different methods of government subsidy and stock price crash risk. Would different methods of subsidy show different effects on the stock price crash risk? This is a promising area for further exploration.

\section{References}

Chen, J., Hong, H., \& Stein, J. C. (2001). Forecasting Crashes: Trading Volume, Past Returns, and Conditional Skewness in Stock Prices. Journal of Financial Economics, 61, 345-381. http://dx.doi.org/10.1016/S0304-405X(01)00066-6

Chen, X., \& Li, J. (2001). Exploring the Role of Local Government Fiscal Supports in Accounting Performance of the Listed Companies. Accounting Research, No. 12, 20-28.

Kim, J. B., Li, Y., \& Zhang, L. (2011). Corporate Tax Avoidance and Stock Price Crash Risk: 
Firm-Level Analysis. Journal of Financial Economics, 100, 639-662. http://dx.doi.org/10.1016/j.jfineco.2010.07.007

Kim, J., \& Zhang, L. (2012) Accounting Conservatism and Stock Price Crash Risk: Firm-Level Evidence. Contemporary Accounting Research, 33.

Piotroski, J. D., Wong, T. J., \& Zhang, T. (2015). Political Incentives to Suppress Negative Information: Evidence from Chinese Listed Firms. Journal of Accounting Research, 53, 405-459. http://dx.doi.org/10.1111/1475-679X.12071

Romer, D. (1992). Rational Asset Price Movements without News. NBER Working Papers, 83, 1112-1130.

Shi, X. W., Hu, Q., \& Xu, F. T. (2014). Marketalization Process, Accounting Information Quality and Stock Price Crash Risk. Journal of Zhongnan University of Economics and Law, No. 4.

Tang, Q. Q., \& Luo, D. L. (2007). The Empirical Study of the Motivation and the Effect of the Government Subsidy-The Empirical Data from China Listed Companies. Financial Research, No. 6A, 149-163.

Tzelepis, D., \& Skuras, D. (2004). The Effects of Regional Capital Subsidy on Firm Performance: An Empirical Study. Journal of Small Business \& Enterprise Development, 11, 121-129. http://dx.doi.org/10.1108/14626000410519155

Zou, C. F., Xu, J. L., \& Wang, Y. P. (2006). Effect of Governmental Tax Preferences and Direct Subsidy on the Performance of Listed Agribusiness. Industrial Economy Research, No. 3, 53 59.

Submit or recommend next manuscript to SCIRP and we will provide best service for you:

Accepting pre-submission inquiries through Email, Facebook, LinkedIn, Twitter, etc.

A wide selection of journals (inclusive of 9 subjects, more than 200 journals)

Providing 24-hour high-quality service

User-friendly online submission system

Fair and swift peer-review system

Efficient typesetting and proofreading procedure

Display of the result of downloads and visits, as well as the number of cited articles

Maximum dissemination of your research work

Submit your manuscript at: http://papersubmission.scirp.org/

Or contact jfrm@scirp.org 